\title{
Druiden
}

\section{i Pennsylvanias dype skoger}

\author{
Eric Cassell var i 40 år indremedisiner i New York. Han ble en pioner innen palliativ medisin, \\ med hypnose som spesialfelt. Han er filosof, kliniker, etiker, gourmetkokk og møbelsnekker \\ og har utgitt sju bøker om legerollen. Hans budskap er at medisinsk teori må endres.
}

- Jeg elsker å kjøre inn denne alleen, sier Eric Cassell da vi svinger av fra landeveien og humper inn mellom nakne, brune trestammer i en amerikansk skog der vissent løv ennå dekker bakken. - Du vet, jeg har kjørt inn her i 75 år nå.

Han humrer i skjegget under kroknese og tykke briller.

Det er mars, snart kommer svartbjørnene ut av hiet og Eric slutter å fôre hjortene og kalkunene som flokker seg utenfor soverommets glassdører hver morgen.

Eric var sju år da hans jødiske ingeniørfar kjøpte sommerhus her i vesle Minisink Hills, noen timers reise fra storbymaset i New York. Nå bor han og kona her det meste av året, avbrutt av korte turer inn til byen hvor de fra leiligheten ved Brooklyn Bridge har utsikt over elven til downtown Manhattan, der World Trade Center for ti år siden raget $\mathrm{i}$ horisonten.

\section{Hypnose, en uutnyttet ressurs}

- Det var litt tilfeldig at jeg begynte med hypnose. Jeg var i 40-årene, drev en travel praksis, fikk vondt i ryggen og oppsøkte en flink fysikalskmedisiner som hadde hjulpet mange av pasientene mine. Han hjalp meg også, med nåler og smertepunktbehandling og annet som jeg ikke kjente til. Jeg spurte om jeg kunne få hospitere hos ham. Jeg har alltid fått lyst å lære det jeg har sett dyktige folk drive med.

Han fortsetter: - En dag ba han meg kikke på noen røntgenbilder av en krum ryggsøyle, klassisk Bekhterevs sykdom. Mens jeg så på bildene, var pasienten kommet inn, krokrygget og stiv, med nesen mot gulvet. Etter en stund hørte jeg legen si: «Og nå kan du rette deg opp.» Jeg snudde meg og fikk se pasienten langsomt rette ryggen, langt mer enn jeg ville trodd var mulig. «Hva skjedde?» spurte jeg da pasienten var ute. «Å, jeg hypnotiserte ham,» var svaret. «Hypnotiserte? Men du kan ikke hypnotisere vekk kyfosen jeg så på de røntgenbildene!» sa jeg.
- Slik lærte jeg to ting - at krumningen delvis skyldtes muskelspasmer og smerte og at hypnose er en reell ting som kan brukes. Da samme lege senere viste meg en film der en kvinne ble forløst med keisersnitt mens hun sang av full hals under hypnotisk anestesi, måtte jeg innse at alt jeg hadde trodd jeg visste om smertefysiologi og et par andre ting, måtte revurderes.

Cassell tok kurs i hypnose, øvde seg på barna og andre «frivillige», men hadde vanskelig for å komme over terskelen og ta den nye teknikken i bruk klinisk. En dag ringte en av hans kvinnelige pasienter og

\section{«Medisinens faglige selvtilfredshet står i skjærende kontrast til dens dype uvitenhet om viktige aspekter ved menneskers helse»}

tryglet ham om å komme til henne på den andre siden av New York, hun hadde fått skulderen av ledd og legene fikk den ikke på plass. Dette var i 1970-årene, da en amerikansk primærlege fortsatt hadde ansvaret for sine pasienter 24 timer i døgnet, også når de var innlagt $i$ sykehus.

Eric Cassell dro av sted. Kvinnen hadde store smerter, skulderen var åpenbart ute av ledd, og legen i akuttmottaket var svett og oppgitt. Hva har jeg å tape, tenkte Cassell og satte i gang transeprosedyren han hadde lært på kurset. Uten store forhåpninger instruerte han kvinnen til å la musklene i skulderen slappe av slik at armen kunne gli på plass.

- Den som var mest overrasket av oss tre da legen uten motstand kunne reponere skulderen var jeg. Fra da av begynte jeg å bruke hypnose i behandlingen av pasienter som jeg ellers strevde med å hjelpe. Særlig i kreftbehandlingen ble det en stor forandring. Etter hvert ble mange terminale kreftpasienter henvist til meg, og jeg fikk erfaring med å følge mennesker gjennom sorg- og dødsprosesser, med tilhørende kroppslige forandringer, sier han.

- Jeg har opplevd at det er mulig å gjøre mye som jeg ville ansett som det rene vås og drømmeri da jeg var ung lege. Igjen har jeg lært to ting - den ene er at medisinens faglige selvtilfredshet står i skjærende kontrast til dens dype uvitenhet om viktige aspekter ved menneskers helse, den andre at hypnotiske fenomener ikke er noe mystisk. De er egenskaper som kan tas i bruk, som så mye annet fascinerende våre kropper kan, uten at vi kan forklare det. Når vi går på to ned en trapp, snakker i telefonen og tygger tyggegummi samtidig, er det også uforklarlig og uten bevisst kontroll. Men siden alle gjør slikt, tenker vi ikke over hvor imponerende og merkelig det er. Jeg har lært å hensette meg i transe hvis jeg brenner meg på komfyren - slik unngår jeg smerte og blemmer på fingrene. Er det mer magisk enn at jeg kan kjøre bil, snakke, drømme, forstå hva du sier?

Jeg lytter med en viss skepsis. Neste kveld søler den litt skjelvende 82-åringen kokende melk på hele høyre tommel mens vi forbereder aftenens kulinariske høytidsstund, slik vi gjør hver kveld. Han tørker med en klut, lukker øynene, støtter seg til benken et halvt minutts tid, blir litt blekere i ansiktet. Så åpner han øynene og smiler. - Man må gjøre det med én gang, før brannskadefysiologien har kommet skikkelig i gang. Jeg aner ikke hvordan det skjer, jeg henvender meg taust til noe jeg kaller «kropp» og har en opplevelse av å få hjelp av noe i meg selv.

Neste dag er huden så vidt rosa. Smerte har han ikke kjent. 


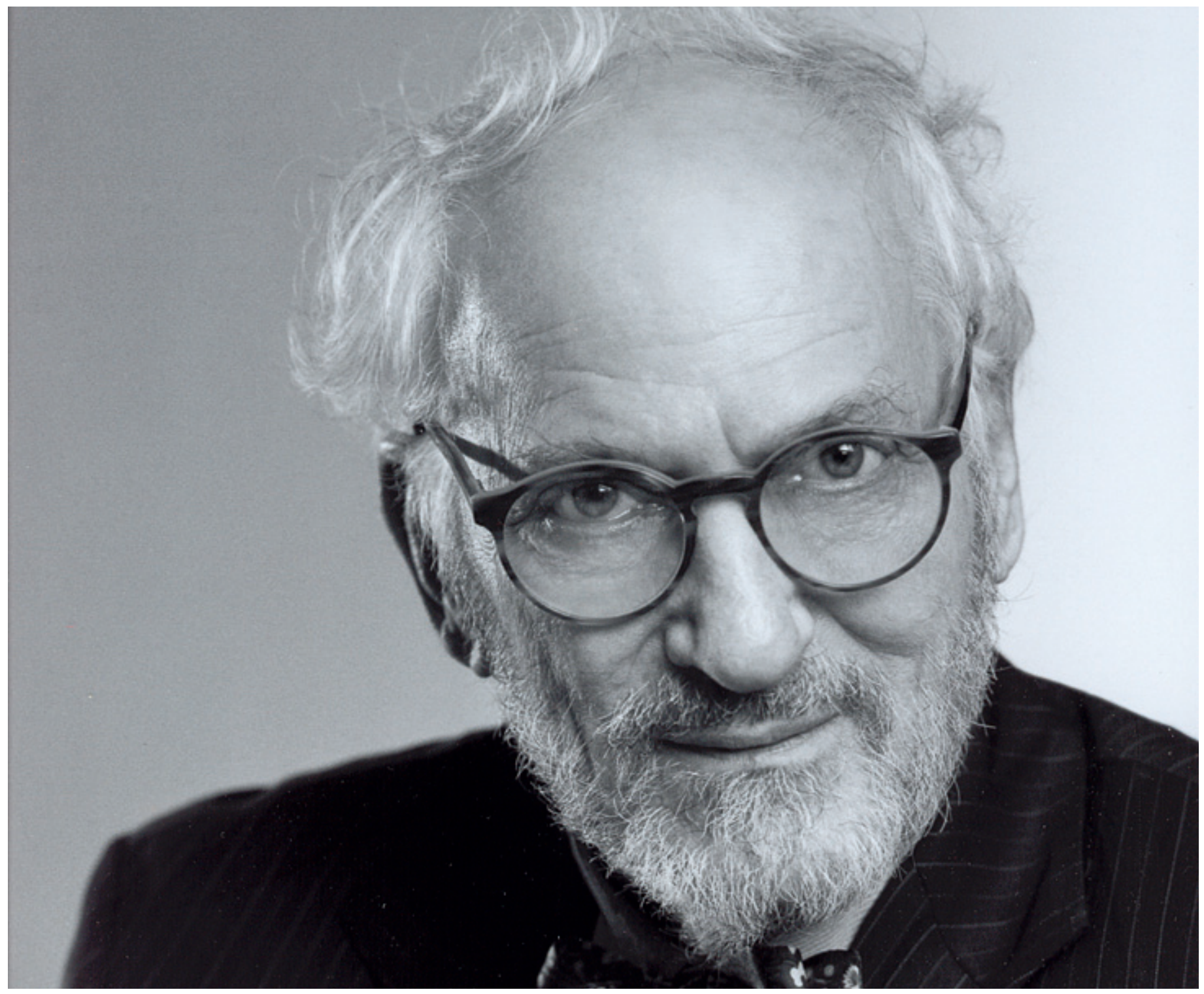

Foto Hiro, New York

\section{Eric Cassell}

Født 29. august 1928 i New York

- Indremedisiner, etiker, primærlege og palliativ medisiner i New York i perioden 1960-98. Professor i samfunnsmedisin ved Cornell University 1971-2007

- Lifetime Achievement Award fra American Society of Humanities and Bioethics, 2005

- Hovedverk: The nature of suffering and the goals of medicine. 2. utg. Oxford: Oxford University Press, 2003. Doctoring: the nature of primary care medicine. Oxford: Oxford University Press, 1997

- Under utgivelse: The nature of healing. Oxford University Press

- På Internett: vimeo.com/4747807

\section{Lesing er nødvendig}

I annen etasje i den ominnredede låven har Eric et høyloftet kontor med vinduer på tre vegger. Den fjerde vender mot biblioteket, hvor hylle etter hylle etter hylle er fylt fra gulv til tak av de deiligste bøker, katalogisert etter National Library of Medicines system, så han kan slå opp på PC-en og finne hvor bøkene står.

Jeg passerer bokhyllene på vei til soverommet og må ofte stanse for å bla eller bare lese på bokryggene. Hvor har han funnet tid og pågangsmot til å lese Hegel, Husserl og Heidegger på egen hånd - og Aristoteles, Arendt og Adorno? Jeg vandrer blant hundretalls filosofibøker, meter etter meter av bokrygger med kjærlighet og sex, historie, zenbuddhisme, språk, lingvistikk og kommunikasjon, Mozart, moderne billedkunst, møbelsnekring, bibeltolking og jødedom.
Innerst finner jeg avdelingen for det mannen egentlig driver med. Her er verkene om medisinens utvikling fra Hippokrates til psykonevroimmunologi, om hypnose og om lege-pasient-forholdet, om psykoanalyse, om medisinsk håndverk og teknikk, vitenskap, profesjonalitet og bioetikk.

\section{Lange arbeidsdager}

I årene 1960-90 jobbet Cassell 14-18 timer i døgnet. - Jeg hadde en travel praksis i New York. Etter hvert ble jeg motelege, hadde mange berømte mennesker som pasienter. Jeg hadde kveldspraksis fra klokken 17 til klokken 21 og mange ansatte. Gradvis ble det så mye å gjøre at jeg sjelden kom hjem før midnatt. Da klarte jeg ikke å sove, måtte ta meg en drink og lese en time. Opp halv åtte.

Han smiler og strekker seg. - Jeg blir 
trett bare av å tenke på hvordan det var å stå opp. Brukte en time med ungene hver morgen. Når de var gått på skolen, leste jeg filosofi en halv time, løp en tur, skrev artikler og bøker. Så var det visitt hos mine egne pasienter på sykehuset før jeg dro på kontoret igjen.

Da han var 58 år gammel, flyttet kona fra ham. - Mitt sorgarbeid ble å bruke det fine kjøkkenet jeg hadde bygd til henne. Jeg kunne ikke lage mat. Begynte med det kinesiske, så det indiske kjøkken. Slik lærte jeg om krydder. Det jeg er mest stolt av i mitt liv er bryllupsmiddagen for en indisk venns datter - 20 retter til 70 gjester.

I 1970-årene begynte Cassell å forske på lege-pasient-samtaler. Mer enn tusen timer lydbåndopptak ble omsatt $\mathrm{i}$ tobindsverket Talking with patients (utgitt 1985). Han ble styremedlem ved Hastings-senteret i New York, som på den tiden var verdensledende på områdene bioetikk og medisinsk filosofi.

- Der var alle de skarpeste hodene jeg noensinne hadde møtt - Stephen Toulmin, Alasdair McIntyre, Hans Jonas. Jeg var sååå naiv. Og jeg merket at disse gutta var flinkere enn meg til å tenke. Så jeg begynte å lese og fant folk som kunne forklare, jeg betalte dem for det. Det tok meg fem år å lese Whitehead, og da var jeg blitt bedre til å tenke. Så brukte jeg sju år på Hegel. Jeg leste mange bøker om logikk. Det hjalp.

Eric Cassels mest kjente bok, The nature of suffering and the goals of medicine, kom ut i 1991. Den er en skarp gjennomgang av de faglige og etiske problemene som oppstår fordi klinisk medisin er teoretisk forankret i sykdomslære og naturvitenskap, ikke i kunnskapen om personer og det erfarte liv - kjernen i menneskelig væren.

Under et forskningsopphold i Boston i 2005 brukte jeg denne boken i studentundervisningen og skrev i takknemlighet til forfatteren. En uke senere ringte han og inviterte hele familien Schei til Pennsylvania. Senere har Eric Cassell vært to ganger i Norge, på seminarer i regi av Filosofisk poliklinikk i Bergen.

\section{Medisinen vet ingenting \\ om mennesker}

- Alle kloke leger vet at det er problemer med vår tids medisin fordi den ikke har peiling på mennesker og levd liv - alt dette som kommer før, under, over, ved siden av, foran og etter det syke organet. To diabetikere som reagerer helt ulikt på å være syk, som har forskjellige styrker og svakheter, oppgaver, intelligens og livserfaringer har de samme helseproblem? Selvsagt ikke! Skal de behandles likt? Selvsagt ikke! Kan leger slå opp i bøker og metaanalyser

\section{«And you know there} are three things you have to know as an old man: Never miss an opportunity to pee, never trust a fart, and never waste a hard-on!»

og vite hva de skal gjøre med diabetikere? Selvsagt ikke! Det finnes bare én måte å lære hva som er denne diabetikerens problem i går, i dag og i fremtiden, og det er å lytte til hva han har å fortelle!

Utropstegnene står tett når Eric Cassell blir engasjert. - Og selvfølgelig må legen kunne sykdomslære, patofysiologi og farmakologi, hele ruklet. Det er fantastisk, det jeg har opplevd i mitt legeliv. Jeg kom inn i medisinen samtidig som de største teknologiske fremskrittene slo gjennom.

Han fortsetter: - Som 15-åring var jeg ekstrahjelp på et sykehus i New York. Det var i 1943. Da hørte jeg to leger utenfor en dør snakke om at pasienten der inne skulle dø. Av erysipelas, en farlig infeksjon den gang. Det var en ung kvinne. Legene hadde samme dag fått noen doser av en ny medisin som het penicillin. «Vi kan like godt prøve,» sa de og ga henne en injeksjon. Neste dag satt den døende i sengen og sminket seg. Så tro ikke at jeg undervurderer naturvitenskapen. Den er nødvendig, den kan bare ikke ta oss langt nok!

Mens han går sine daglige fem kilometer på tredemøllen, noe han finner kjedelig, men nødvendig i sin høye alder, tenker Eric høyt. - Å lytte til hva folk har å fortelle deg, det er kunsten. Og det er mye vanskeligere enn folk og leger tror. Å lytte, det er ikke noe akustisk eller språklig. Det er å tenke klart, få tak i meningen i det den andre sier, symptomene i alle detaljer, hva som faktisk har skjedd, hva som bekymrer, hvordan hun ser ut mens hun snakker, hvordan hun puster, hva hun ikke snakker om, hva hun lengter etter, hvem som er viktig i livet hennes, hva som for all del ikke må skje. Du kan bare klare å lytte hvis du er konsentrert og kreativ, hvis du setter dine egne tanker og ideer i parentes, hvis du lar den andre føre deg dit hennes ord tar deg, et sted du ikke hadde tenkt fantes. Du må være nysgjerrig, pågående, villig til å ydmyke deg, ta feil, bli fortalt. Og du må vite noe om hva det er å være menneske, og noe om deg selv. Folk merker det, og da kommer de på viktige ting å si. Ofte akkurat det du trenger for å løse problemet.

- Noen sier det er en kunst å eldes. Hva sier du, Eric?

- Den kunsten består av flaks, kjærlighet, skjønnhet og mosjon. Samt noen dråper lekenhet - og god whisky. Han ser lurt på meg. - And you know there are three things you have to know as an old man: Never miss an opportunity to pee, never trust a fart, and never waste a hard-on!

\section{Edvin Schei}

edvin.schei@isf.uib.no

Universitetet i Bergen 